\title{
Chinese overseas M\&A: overcoming cultural and organisational divides
}

\author{
Francesca Spigarelli* \\ Department of Law, \\ University of Macerata, \\ via Angeloni, 3 Jesi (An), Italy \\ Fax: +39-0733-2588812 \\ E-mail: spigarelli@unimc.it \\ *Corresponding author
}

\section{Ilan Alon}

Department of International Business, Rollins College,

Winter Park, 100o Holt Avenue, 32789 Florida, USA

Fax: +1-407-646-1566

E-mail: ialon@rollins.edu

\author{
Attilio Mucelli \\ Department of Management, \\ College of Economics 'Giorgio Fuà', \\ Polytechnic University of Marche, \\ Piazzale Martelli, 8 - 60121 Ancona, Italy \\ Fax: +39-071-2207199 \\ E-mail: a.mucelli@univpm.it
}

\begin{abstract}
This article contributes to the existing knowledge on the difficulties and critical aspects of the post-acquisition phase of an emerging market multinational. To establish the context, a literature review on multinational companies from emerging countries, and specifically on the internationalisation initiatives of Chinese companies, is provided, along with a framework to analyse cultural and management-related differences related to mergers and acquisitions (M\&As). This review and framework is followed by a case study of a Chinese M\&A in Italy. The case illustrates how Chinese companies use Italy to access Western markets (and strategic logistical services), as well as a wide range of distinct skills/intangible assets, such as brands, know-how and technology, particularly in the manufacturing industries. The findings suggest that while superficial product-portfolio and cost benefits can accrue due to the acquisition, cultural and administrative differences and lack of synergies can prevent the acquirer from fully integrating the intangible assets, particularly human resource talent, of the acquired firm.
\end{abstract}

Keywords: merger and acquisitions; emerging markets multinationals; post-acquisition integration problems; case study. 
Reference to this paper should be made as follows: Spigarelli, F., Alon, I. and Mucelli, A. (xxxx) 'Chinese overseas M\&A: overcoming cultural and organisational divides', Int. J. Technological Learning, Innovation and Development, Vol. X, No. Y, pp.000-000.

Biographical notes: Francesca Spigarelli is an Assistant Professor at the University of Macerata. She teaches Economics and Managerial Economics in the Faculty of Law. She received her PhD from the University of Pescara, Italy, in Banking and finance. Her main research topics are SMEs internationalisation processes, foreign direct investments, multinational companies from emerging countries, M\&As with specific focus on Chinese context. She is the author of several articles and book chapters in international publications. She also has significant experience as consultant and as executive and MBA trainer in the field of internationalisation processes of small and medium companies.

Ilan Alon is a George D. and Harriet W. Cornell Chair of International Business, the Director of The China Center at Rollins College, and Visiting Scholar and Asia Fellow at Harvard University. He teaches undergraduate and graduate courses relating to International Business management and marketing at Rollins College. He also has significant executive and MBA education and consulting experiences in Europe, Asia, the Middle East and USA. Among his recent books are Chinese International Investments, Chinese Entrepreneurs, China Rules, Globalisation of Chinese Enterprises, Service Franchising: A Global Perspective, Business Education and Emerging Market Economies: Perspectives and Best Practices, and Chinese Economic Transition and International Marketing Strategy.

Attilio Mucelli is an Associate Professor in Management Accounting and Financial Accounting. His main research topic is related to management and cultural problems in internationalisation processes of firms. Special focus on investments by companies from BRIC countries (Brazil, Russia, India, China) in the Western markets, with specific reference to Chinese Go Global strategy and to Chinese M\&As abroad. He is also focused on relational capital analysis, measurement and evaluation systems; intellectual capital measurement and evaluation systems and management of innovation process. He teaches management accounting and planning and control systems in the College of Economics 'Giorgio Fuà' of Polytechnic University of Marche. He is also the Director of the Master programme in Finance at ISTAO Business School (An, Italy).

This paper is a revised and expanded version of a paper entitled 'Integration problems in Chinese overseas M\&As: a case study approach’ presented at 2nd Copenhagen Conference on Emerging Multinationals held at Copenhagen Business School, Copenhagen, Denmark, 25-26 November 2010.

\section{Introduction}

One of the most interesting phenomena that has recently emerged in international finance and economics is the leading role of the emerging economies as global investors (UNCTAD, 2006). New multinational enterprises (MNEs), primarily from the Brazil, Russia, India and China (BRIC) countries, have embarked upon rapid globalisation processes targeting the industrialised economies, particularly Europe and the USA 
(Sauvant, 2005, 2006; Wilson and Purushothaman, 2003). In the context of the new MNEs from emerging countries, China represents a most significant case (Alon et al., 2009; Alon and McIntyre, 2008; Zweig, 2002).

Recent studies not only emphasise the specific nature of internationalisation processes actively promoted by the government, but also provide evidence of the weaknesses associated with such internationalisation processes. Consulting firms, among others, have reported cases of bankruptcy or serious difficulties encountered by emerging market multinationals in international markets (Accenture, 2005). By the end of 2008, $70 \%$ of overseas M\&As by Chinese enterprises had failed (People's Daily Online, 2009), whereas the volume of such M\&As increased nearly 20-fold between 2000 and 2005 (Boateng et al., 2008). Despite the high profile cases of failure and the widespread problems in post-purchase integration, Chinese investment continues to grow. The 2008 financial crisis did not appease Chinese appetite for foreign targets (APFC and CCPIT, 2009; MOFCOM, 2009), even though global M\&As fell by $65 \%$ (or by $34 \%$ in value) in 2009 [UNCTAD, (2010), p.10]. The drop was particularly serious in the industrialised countries (-44\%) and also for MNEs in the emerging markets (-26\%). Nevertheless, China was an exception: M\&As grew by 41\% (UNCTAD, 2010, Tables 12 and 17) in 2009, with an estimated 300 new deals concluded in 2009 [EIU, (2009), p.4] and a surge in Chinese acquisitions reported in 2010 [UNCTAD, (2011), p.201]. In this context, China - with its so-called 'Go Global' strategy - represents one of the most interesting cases discussed by both scholars and experts (Alon et al., 2009; Alon and McIntyre, 2008; Zweig, 2002).

A critical issue is the effective ability of Chinese enterprises operating abroad to absorb new technology, to use new brands, to invest in marketing and intangible assets, and, above all, to become accustomed to Western standards in terms of management practices and corporate governance regulations. These problems become increasingly striking in the case of international mergers and acquisitions (M\&As), where there may also be cultural problems, especially if M\&As are not accompanied by an adequate training programme for the managerial and professional classes (Tan, 2005; Bert et al., 2009).

The purpose of this article is to contribute to the current knowledge on the critical difficulties related to M\&As by new Chinese global players in the post-acquisition phase. Specific attention is paid to integration issues related to human resources and management practices.

The article is organised as follows. First, a literature review on MNEs from emerging countries is presented, with particular reference to China and Chinese acquisitions. A framework for analysing cultural and management-related M\&A problems is then proposed. In the second part of the article, we focus on a case study of a Chinese M\&A in Italy, examining the strategic motivations behind the acquisition and the critical problems in the interactions between the Chinese investor and the acquired Italian firm. We conclude with a discussion of our analysis and more generalised applications to Chinese M\&A. 


\section{Literature review}

Following the appearance on the global scene of new multinationals from the emerging economies (Bartlett and Ghoshal, 2000), there has emerged a new body of literature (Bonaglia et al., 2007; Mathews, 2002; Meyer, 1998, 2008; Ramamurti, 2009; Sauvant, 2008). In the early 1990s, new global players included a growing number of enterprises from Chile, China, Egypt, Malaysia, Mexico, Russia, South Africa, Thailand, and Turkey [Aykut and Goldstein, (2006), pp.8, 11-12; UNCTAD, (2006), pp.18-36].

These enterprises, driven by the search for competitive advantages, follow atypical patterns of development: they internationalise in order to grow and they make ample use of alliances and acquisitions so as to acquire distinctive resources, including brands, technology, and knowledge (Gammeltoft, 2008). These resources contribute to the rapid creation of an international competitive advantage capable of expanding and diversifying their core competencies.

Many enterprises, and not only large or publicly controlled companies, have globalised, leveraging government support in terms of fiscal and financial aid, operating services, and assistance (Bellabona and Spigarelli, 2007). Globalisation occurs through Greenfield and Brownfield initiatives, and especially through acquisitions of existing assets (Hess, 2006; Rui and Yip, 2008). Increasingly, Chinese companies are moving beyond the initial search for sources of energy and raw materials (Lawrence, 2002): recent empirical analyses (Battat, 2006; Jiang, 2006; Zhang, 2005) show that enterprises frequently internationalise in order to conquer new markets (Cross and Voss, 2008; Liu and Tian, 2008) due to the strong competition and saturation in their domestic markets (Buckley

et al., 2008; Deng, 2004; Morck et al., 2008; Taylor, 2002; Zhang, 2003). The new multinationals seek to reduce production costs and overcome commercial barriers. By acquiring Western companies, they secure advanced technologies and strategic competencies, including managerial skills (Cross and Voss, 2008) and internationally recognised brands so as to avoid long market-acceptance times (Morck et al., 2008; Rui and Yip, 2008).

Despite the significant impact that the Chinese Go Global strategy is having at an international level, there are also signs of weakness and fragility inherent in an 'induced' internationalisation process. First, a problematic issue associated with the Go Global policy is that government support for the internationalisation of Chinese enterprises is an integral part of its economic diplomacy, and its strategic, political and economic objectives are frequently confused (Yeung and Liu, 2008). During the most recent phase of expansion, primarily focusing on intangible assets, government intervention has been viewed with suspicion and has slowed or prevented agreements, alliances and acquisitions, similar to what occurred in the past in other Asian countries (Goldstein, 2008).

Second, the organisational structure of conglomerates limits the efficacy of their actions in a global context and their advantages of scale frequently are a matter of mere appearance. For historical and governance-related reasons, subsidiaries tend to operate as quasi-independent entities, often pursuing goals that conflict with the strategies outlined by the government or on behalf of the government by holding companies (Nolan, 2001; Nolan and Zhang, 2002). There have been numerous cases of bankruptcy or of encountering serious difficulties in international markets (Accenture, 2005; Alon et al., 2011). 
Another critical issue, which has been the subject of extensive debate in both academic and Chinese management circles, is the effective ability of Chinese enterprises operating abroad to absorb technology, especially where an adequate training programme for the managerial and professional classes is lacking (Tan, 2005). Even when such absorptive capacities are developed, the more fundamental competencies, i.e., the ability to develop new related technologies, are often not internalised.

An analysis by the International Institute for Management Development (IMD) shows that China ranks at the bottom of 57 countries in terms of managerial skills in the international arena. This creates huge operational problems for both multinationals and locally-owned companies. Furthermore, China's ranking in terms of management practices is also low (ranking no. 51), indicating that Chinese managers need to acquire more leadership qualifications and develop soft skills (Rossele-McCauley, 2009).

As yet, there has been little research on Chinese M\&As (Boateng et al., 2008; Deng, 2007, 2009; Rui and Yip, 2008). However, a limited number of contributions are specifically devoted to M\&As as the preferred Chinese mode of expansion (Alon et al., 2011). Some papers challenge the research by Child and Rodrigues (2005) that questions whether Chinese international expansion is "institutionally embedded rather than reflecting a strategic choice by the leaders of firms". From an institutional perspective, the acquisition of strategic resources by Chinese firms is influenced at the individual, firm, and inter-firm levels by the institutional context (Deng, 2009; Oliver, 1997). In such cases, M\&As represent a response to the unique institutional characteristics in China. However, other research proposes a strategic intent perspective (SIP) to explain the foreign acquisitions by Chinese firms. In this approach, "Chinese firms strategically use cross-border M\&As to achieve specific goals, such as acquiring strategic capabilities to offset their competitive weaknesses and leveraging their unique ownership advantages, while making use of institutional incentives and minimizing institutional constraints" (Rui and Yip, 2008).

In addition to the theoretical contributions, there are several empirical studies that shed light on some key aspects of Chinese M\&As. As latecomers, Chinese MNEs use acquisitions to enable rapid access to strategic assets so as to face global competitors (Deng, 2007). ${ }^{1}$ This is why M\&As are becoming the dominant vehicle for outward operations by Chinese enterprises [OECD, (2008), p.66]: more than $80 \%$ of the value of Chinese outward FDI is carried out via M\&As (OECD, 2008). The goals of Chinese firms are market development; faster entry into new markets; diversification; advanced foreign technology; R\&D competencies and management know-how (Liu and Li, 2002; Boateng et al., 2008; OECD, 2008). The buyers are mainly large enterprise groups with competitive and comparative advantages at the international level (Chen and Li, 2006; Morgan Stanley, 2005). The acquired firms, which are usually based in the developed countries, face financial or strategic difficulties (Morgan Stanley, 2005). Deals are concentrated in some key industries, such as resources and energy, telecommunications, electronics, machinery, home appliances, and automobiles. These sectors are characterised by fierce competition between local firms and global rivals (Rui and Yip, 2008).

Focusing on problems that Chinese companies face in managing overseas M\&As, Hirt and Orr (2006) identify some critical issues, such as handling relationships with skeptical regulators, unions, and other stakeholders before, during, and after the deal. There are also issues related to globalising the brand, the supply chain, and the sales 
network. Chinese firms face unfamiliar environments where business practices, models and routines, as well as administrative, fiscal and civil regulations completely differ from those in China. In any event, the most relevant/critical factor in managing overseas acquisitions seems to be the need to integrate people and to bridge the cultural gaps between the Chinese investor and the acquired company. ${ }^{2}$

\section{A framework for assessing critical aspects of Chinese M\&As}

In order to evaluate critical aspects of Chinese M\&As, an analytical framework is proposed, based on the identification of mechanisms that should be put in place by the buyer to leverage the integration process. The framework will be used as a guideline in the case study that follows.

The success of an acquisition is strictly related to management of the phases that follow the transaction (Haspeslagh and Jemison, 1991). Key choices involve both the level of integration between the two parties (whereby the company that has been acquired either loses its identity or maintains its independence) and the possibility/need to replace the managerial resources of the purchased firm (Zollo and Singh, 2004). Research shows that in most cases the buyer follows a structural-integration approach by fully integrating the acquired firm. The acquired company loses its identity and its senior executives are replaced. However, recent studies show that such an approach is frequently not followed in the case of M\&As from emerging countries (Kale and Singh, 2008). In these cases, buyers tend to allow the target firm to remain structurally separate. By keeping the acquired company's identity and retaining its senior employees, the buyer is hoping to preserve routines, expertise and knowledge. As a result, the acquisition is somewhat more akin to a strategic alliance. To promote synergy and leverage interdependence, the buyers must follow a 'partnering approach to acquisitions' (Kale and Singh, 2009). Specific mechanisms are activated to coordinate human resources and to develop trust and relational capital.

Figure 1 Key aspects of the post-acquisition phase (see online version for colours)

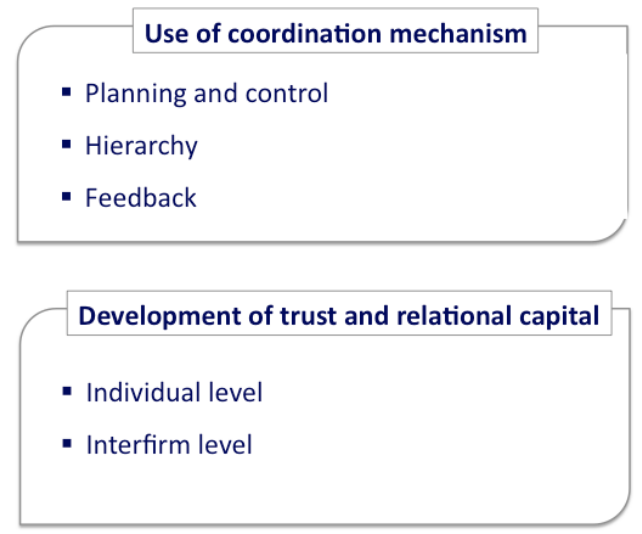

There are three specific mechanisms to coordinate human resources (Galbraith, 1977). The first, related to 'planning and control', involves setting specific tools to identify the strategic and operational roles of each firm, the responsibilities in the 
production/distribution process and the timetable for implementing strategic and operational goals. The second mechanism, involving hierarchy, clearly defines the formal structures with respect to the authority/responsibility of human resources and decision-making power. The third mechanism, feedback, involves information-sharing instruments and information-flow processes used to 'link' the two firms.

The need to develop trust and relational capital is related to behavioural attitudes: people in both firms need to share and integrate their knowledge in the interest of 'the group' as a single body. Trust-building mechanisms involve the creation of both personal bonds, encouraging people to understand and accept different styles/attitudes/behaviour (Schreiner et al., 2009), and inter-firm trust that depends on institutional factors such as the firms' location and national culture (Dyer and Chu, 2003; McEvily et al., 2003).

Figure 1 summarises the key issues investigated and analysed and in the case study.

\section{The case study: a Chinese acquisition of an Italian firm}

The following case study, based on the framework described in Figure 1, is intended to deepen our understanding of critical aspects of Chinese M\&As (Yin, 1989). ${ }^{3}$

The deal in question took place in Italy in September 2005 when Italy became a recipient of investment from the Chinese Go Global policy. Italy provided Chinese companies with rapid access to Western markets (and strategic logistical services), as well as to a wide range of distinctive skills/intangible assets, such as brands, know-how and technology, in the manufacturing industries (Spigarelli, 2010).

\subsection{The context}

To better qualify the results and to allow the reader to transfer specific knowledge to other contexts, it is important to state the particular context in which the case study took place. Cultural dimension models can be very useful for this purpose. On the basis of both Hofstede and Globe model results (Franke et al., 1991; House et al., 2004), Italy and China have very different cultural backgrounds and values that are reflected in different business behaviours and business approaches. Italy has a high degree of individualism and is a male chauvinist society, whereas China typically has a long-term orientation. Institutional and group orientation-collectivism is fundamental in China due to the importance of a high sense of belonging. Such cultural aspects have huge consequences for the organisational culture and management style (Spigarelli et al., 2009).

Focusing on the concept of comparative business systems, the Whitley framework is useful to contextualise the case (Whitley, 1999, 2001, 2005). This approach identifies key differences in systems of economic organisation and control in terms of specific features of the institutional environment [Whitley, (1999), p.5]. Three types of business environment (BE) (particularistic, collaborative and arm's length) emerge, on the basis of the institutional arrangements controlling access to capital and skills; the forms of coordination and control of economic activities, leading to different strategic priorities; and forms of owner control and authority sharing, and collective competencies. Collaborative BEs are characterised by the presence of strong institutions that "lock key actors into each others' destinies and so encourage cooperative behavior by restricting exit opportunities” [Whitley, (2001), p.39]. The environment where the deal took place 
and where the acquired firm actually operates (Italy) can be considered 'collaborative'. In the provincial area where the acquired company is based, local government organisations and trade unions have a high degree of involvement in economic activities and as a result played a fundamental role in bringing the deal to fruition in 2005.

Another significant issue raised by Whitley - also useful to contextualise the case study - is related to modification of the links of the firm with the business system of origin $^{4}$ when internationalisation processes occur, leading to new governance structures and capabilities. The extent of these changes depends on the size of the foreign subsidiaries relative to the size of the domestic firms, the location of the foreign units, the characteristics of the host business system and the type of investment (in technologically advanced and rich markets vs. poor markets with cost advantages) [Whitley, (2001), p.65].

Four ideal types of internationalisation are conceptualised (similar multi-domestic; fragmented; similar integrated; hybrid) on the basis of the extent of the organisational integration of routines and the variety of BEs in which the MNC operates. See Figure 2.

Figure 2 Modes of internationalisation

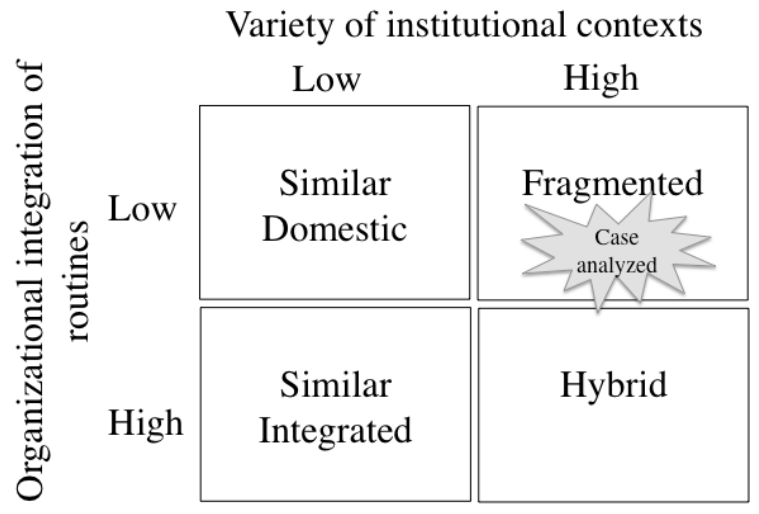

Source: Whitley (2001, p.36)

Fragmented MNCs seem to be the most appropriate category to describe our case. Learning differs between Italy and China and the parent company seems - up to the present - unable to grasp some key competencies from the acquired company due to the huge differences in business approaches that are partly linked to the institutional context. Therefore, the case study is relevant because many Chinese M\&As in Western markets, specifically in the manufacturing sector, fall into this category, particularly when state-owned transnational corporations are involved. ${ }^{5}$ The motor vehicle industry - that is involved in the case - is one of the major industrial targets of FDI outflows from East Asia [UNCTAD, (2011), p.48], whereby the buyer is seeking advanced, proprietary technology, brand names and distribution channels (Buckley et al., 2007).

\subsection{The Chinese acquirer and the Italian target acquisition}

In our case study, the buyer is a state-owned group situated Zhejiang province in southeast China. It is one of the main Chinese companies that manufactures and markets motorcycles (ranging from 50 cc to 250 cc) and engine parts. Production also covers a 
wide range of other machinery and electrical products. Due to an annual output of more than 1,000,000 units, the company holds about $7 \%$ of market share in China. Approximately $40 \%$ of the turnover is exported to more than 110 countries.

The acquired company is a small Italian firm which designs and produces motorcycles (in the heavy segment of the market, i.e., motorbikes with a displacement of more than 650 cc) and scooters. It was established as a family firm in 1911, initially offering automobile and motorcycle repairs, as well as the manufacture of spare parts. An impressive knowledge base and a range of technical expertise led the firm to begin manufacturing motorcycles and to enter the world of competitive sports. In 1921, at the Third International Bicycle and Motorcycle Exhibition in Milan, its first motorcycle was presented to the public. Numerous national and international titles were won, leading to increased visibility and success in the European market. The company reached its peak before the Second World War, when it employed about 800 persons. However, the golden age of the firm came to an end in the 1960s due to strong competition from Japanese producers. Furthermore, many changes in equity occurred with unsuccessful attempts to re-launch the company. In 2005, as a result of huge financial problems and poor market-share performance, production came to a halt and the company went into liquidation.

\subsection{The strategic motivation behind the $M \& A$}

The focus of the Chinese company through the M\&A was the motorcycle industry. The acquired company had products in both the scooter sector and in the heavy segment of the industry, offering 'naked' or standard bikes, sport, and touring models. The Chinese firm focused more on the low price segment of the market, offering a wide range of scooters and standard products in a variety of models.

Through the acquisition, the Chinese MNE could access the know-how and highly-developed design skills of the Italian counterpart. Such distinctive knowledge was considered by the Chinese investor to be a strategic resource, offering new high-quality products and penetrating new segments of the market (by improving its own portfolio range), as well as increasing the quality of its traditional products (typically scooters). Another strategic motivation behind the acquisition was the reputation of the Italian brand, which was well known for its quality and sporting tradition (Spigarelli et al., 2009).

Increased market visibility and a wide range of quality products should have helped the buyer compete with the leading Japanese firms that were combining innovative designs, engine performance and low prices. It was envisioned that the acquired company would embody Italian design, Japanese quality and Chinese cost capabilities.

\subsection{The post-acquisition phase}

Before introducing our specific framework-driven analysis, some basic information on the post-acquisition phase will be useful to better understand the case. From the outset, the Chinese leadership focused on the restructuring of the company's production processes, thereby lowering costs. Increasing efficiency and production capacity were considered fundamental to reducing production costs and to bringing sales prices to more competitive levels. The new enterprise planned an increase both in the workforce (to be 
doubled within two years) and in the range of products offered in the market (with six new models to be launched within four years).

No changes in administration and R\&D activities were planned. Only several people from China were relocated to Italy: the sales director, the parts quality manager and the managing director.

Despite the positive changes that the acquisition brought about, some problems emerged during the integration process, due primarily to the cultural differences between Chinese and Italians in general terms of attitudes and lifestyles and in particular in terms of business approaches.

The Italian technical director who was appointed vice managing director by the Chinese investors left the company in 2010 due to his opposition to the way the Chinese were running the firm (Miller, 2011). He had been the 'historical heart' of the company.

Moreover, sales performance as well as economic/financial results remained unsatisfactory compared to Chinese plans and the potential of the acquired firm. The number of products registered on the Italian market by the acquired firm dropped from 484 in 2008 to only 163 in 2009. Poor performance could be partially explained by difficult market conditions and the global financial crisis $^{6}$, but market trends are insufficient to justify the weak sales volume, particularly if registrations by direct Italian competitors are taken into consideration (Morini, for example, increased from 351 registrations in 2008 to 353 registrations in 2009, whereas Triumph went from 5,978 to 5,182$)$.

Table 1 reports on the main economic and financial information of the Italian firm pre- and post-acquisition. The value of production dropped significantly after 2008. However, the drop in production costs was not comparable and losses increased steadily. Capital investments declined as well.

Referring back to the framework described in the first part of the paper, problems related to the post-acquisition phase may have been related to the development of relational capital as well as to the coordination of human resources. As for the development of relational capital, after the first 'enthusiastic' phase, human relations became somewhat more complicated. Deficiencies in language skills on both sides, as well as different cultural backgrounds and working habits delayed the development of new products.

English was used as a 'bridge' language, but neither the Italians nor the Chinese were fluent. On occasion the Chinese would speak in Chinese when they disagreed with their Italian colleagues during official meetings. Trust was difficult to build. Moreover, Italian and Chinese workers seem to have had different perceptions of time and punctuality. In part, this can be related to different levels of commitment to work. Whereas Chinese workers tend to have a strong commitment to the success of the firm, the more individualistic Italian culture weakens any sense of belonging. Chinese are willing to work at night and on Sundays, whereas Italians considered this quite absurd, even in case of urgent or strategic deadlines.

Regarding conflicts, Chinese seem to be less capable of dealing with conflicts directly and instead try to 'muddle through', creating serious misunderstandings. Several anecdotes collected for this study describe the Chinese habit of not replying to e-mails or answering direct questions on matters with which they disagreed, including also on some issues related to technical problems in the production process that should have been resolved quickly. 
Table 1 Financial and economic data of the acquired company (in thousand $€$ )

\begin{tabular}{lccccc}
\hline & 2001 & 2002 & 2003 & 2004 & $2005^{*}$ \\
\hline Value of production & 17,808 & 17,210 & 23,943 & 15,413 & 535 \\
Production costs & 26,712 & 33,510 & 46,675 & 26,959 & 1,819 \\
Profits/losses & $-11,033$ & $-18,651$ & $-24,642$ & $-9,443$ & $-1,291$ \\
Assets & 53,550 & 47,964 & 42,560 & 32,176 & 9,594 \\
Debts & 53,729 & 51,244 & 45,402 & 41,519 & 10,876 \\
Net equity & -179 & $-3,281$ & $-2,842$ & $-9,342$ & $-1,281$ \\
Investments in R\&D & 3,478 & 1,892 & 881 & 516 & .a. \\
Employees & 104 & 73 & 71 & 74 & 48 \\
Sales abroad & $64 \%$ & $70 \%$ & $58 \%$ & $50 \%$ & n.a. \\
\hline & 2006 & 2007 & 2008 & 2009 & 2010 \\
\hline Value of production & 13,972 & 22,063 & 16,392 & 7,185 & 7,747 \\
Production costs & 17,447 & 24,023 & 19,231 & 10,951 & 12,018 \\
Profits/losses & $-3,849$ & $-1,916$ & $-3,841$ & $-3,522$ & $-4,749$ \\
Assets & 22,178 & 26,902 & 27,009 & 20,829 & 18,982 \\
Debts & 23,294 & 23,507 & 24,623 & 19,844 & 18,642 \\
Net equity & $-1,234$ & 3,218 & 2,206 & 985 & -218 \\
Investments in R\&D & n.a. & 1,836 & n.a. & n.a. & 1,261 \\
Employees & 89 & 97 & 100 & 99 & 95 \\
Sales abroad & n.a. & $70 \%$ & $55 \%$ & $50 \%$ & $69 \%$ \\
\hline
\end{tabular}

Note: *Economic and financial data for 2005 refer only to a 3-month period. The M\&A took place in 2005.

Source: Financial statements and balance sheets of the acquired company

At the intra-firm level, cultural distances and differences in terms of business priorities may explain the Chinese perceived lack of importance of investments in the image of the firm, in market visibility, and in customer care. But such issues are fundamental to be able to compete in the Western motorbike markets. Even the return to competitive racing planned by the Chinese to re-launch the brand was delayed. Market uncertainties and (sometimes) an obsessive search for cost reductions led to the postponement of new investments.

The distribution network in Europe and the USA was weak, whereas customer service was not properly assured. Trademark protection policies were also lacking: one of the two Italian trademarks obtained through the acquisition had expired and an Italian racing team was already using it freely.

Another critical aspect at the intra-firm level relates to the different 'institutional' contexts in terms of civil and fiscal laws. This created several administrative problems and misunderstandings: some decisions/actions by Italian employees appeared to be irrational to Chinese employees and vice versa.

As for coordination of human resources, there was a lack of managerial skills from an international and 'group' perspective. The Chinese firm did not develop sufficient mechanisms to manage and coordinate human resources and information produced for 
planning and control was unidirectional. No feedback was provided on the data sent to China: it was 'kept' by the parent company and used only for internal purposes.

Usually, the strategic objectives of an acquired company were not formalised in a strategic plan. Information on the strategic goals and on the medium- to long-term development plans of the group was only disclosed in times of crisis or when the company faced serious problems.

A budget system, as well as a simplified system of industrial accounting, was put into place. But the budget only focused on sales performance and production costs, whereas industrial information focused only the number of motorbikes and spare parts produced, the number of motorbikes and scooter sold, and the working hours in the plant. Data were sent every three months to the Chinese parent company by e-mail in a digital format. The computer systems of the two companies were not integrated, but the Chinese MNE had direct access to the Italian company's computer system and could get information on items produced and sold. In the past, with the previous owners, more data had been available, especially at the industrial level. Information flows to the buyers are also related to the financial statement. To allow the Chinese MNE to draw up its periodic financial statement, every three months the administrative staff of the Italian firm would complete a financial statement ${ }^{7}$, as well as a stock flow inventory report, a credit and debit analysis report and a cash flow statement.

Even mechanisms related to hierarchy were weak. Apart from the highest position in the company, authorities and levels of responsibility in terms of human resources were not formalised. Decision-making power was highly concentrated in the hands of the managing director.

\section{Conclusions}

We can draw some generalisations from the case findings (Yin, 1989), which can then be verified via a comparative analysis of similar M\&A operations. Two critical areas in the area of management are occurring in the case during the post-acquisition phase: coordination of human resources and development of relational capital.

Communications and interactions are often frustrating. In coordinating human resources, there is a lack of managerial skills from an international and 'group' perspective. Tools to identify strategic and operational roles, responsibility in the production/distribution process, and a timetable for implementing strategic and operational goals are lacking. Coordination is also difficult due to limited definitions of the authority/responsibility of human resources. Decision-making power is highly concentrated, but the most serious problem is related to feedback: information is not shared and the information-flow process is unidirectional.

Focusing on trust and relational capital, there is a need to improve cross-cultural understanding between the two companies to find a common ground between the two cultures. Barriers deriving from habits, language, orientation and cultural approaches to business and management must be overcome. How this is achieved may be prescriptive, but the general choices of acculturation can be divided into three options: maintaining the original culture and system, integrating with the headquarter culture, or developing a third system that combines elements of the two. Strategies for intercultural communications and leadership development have been discussed in the literature (e.g., Alon and Higgins, 2005). 
With respect to the post-acquisition integration of technologies and branding know-how, the absorptive capacity of the acquiring firms to utilise the core competencies of the acquired firm is seriously hampered by organisational and cultural divides. The ability of a firm to develop inter-cultural and inter-organisational consistency is directly related to its ability to succeed in new and foreign markets where there are distinctive political, economic, social and technological environments. Further, while absorbing current technologies and know-how is important, even more important to the dynamic capabilities of the firm is its ability to produce the assets, both tangible and intangible, that initially generated these core competencies. The loss of key personnel may lead to deterioration in the firm's competencies as well as in its connections to the market and to the acquired firm's history and tradition.

Leveraging the history and tradition of a European firm and repositioning the firm for global leadership in the heavy and light bike industry is no small task, especially in the highly competitive American and European markets. The acquired Italian firm was competing in a niche motorcycle market for racing enthusiasts. A Chinese country-of-origin did not contribute to the company's reputation, so the need for good brand stewardship was even more pronounced. Given that some Chinese firms do not fully appreciate or are unable to internalise the value of brand management and marketing, there may be a stronger need to localise these elements.

Further, Italian employees are accustomed to more communication and to combining work/home responsibilities for motivation. The relations Italians form at work are taken home, for example, by celebrating holidays and festivals together. This allows for the building of interpersonal contacts and close working relationships that nurture the building of trust and cohesion. For Chinese, work is a part of life and devotion to work may extend to family circles. Long hours and/or great personal sacrifices are not unimaginable. For the Chinese employees in the Italian factory, this was already the case. Separated both physically and culturally from their home country, they sought one another's company and felt more comfortable speaking their own language with fellow nationals. This created fiefdoms and silos within the organisation making it difficult to coordinate the building of the most important intangible resource, i.e., human resources. Such organisational uncertainty can create alienation and a sense of desperation among key figures, leading to personnel departures and ultimately failure to achieve production and marketing goals.

In this case study, it is possible that the technology know-how gained by the acquiring organisation was worth the acquisition price, regardless of the outcome on the acquired organisation. Much was absorbed regarding design, manufacturing, branding and cross-cultural communications and management. If the Chinese headquarter can apply some of these learned skills across the organisation, diffusing best practices and learning from mistakes, much will be considered gained and the acquisition may in the end provide multiple dividends.

\section{Discussion}

This paper contributes to the literature and to the academic debate on MNE from emerging markets. Use a case of a Chinese acquisition of an Italian firm, our analysis confirms the difficulties that organisational and cultural divides have on the exploitation 
of resources using international M\&A. As indicated by the extant research, Chinese face difficulties in integrating the acquired firms, particularly over the medium term (Hirt and Orr, 2006). After an initial phase of 'enthusiasm', a 'growing discomfort' emerges. Differences between Western and Chinese business systems exacerbate difficulties and reduce the potential for a successful integration process. As revealed by the Whitley model, the transferability of practices and routines during the internationalisation process is discouraged due to varied labour-market institutions and differing state structures, policies and financial systems. "MNCs from a distinctive and cohesive business system with strong associated institutions governing economic activities may well become more complex and differentiated as a result of FDI [...] but are unlikely to change their fundamental characteristics" [Whitley, (2001), p.64].

The absorptive capacity of the Chinese MNEs is limited, as defined by Whitley, particularly in terms of human resources and marketing strategies; whereas in terms of production and engineering, the Chinese are keen to learn and capitalise on this knowledge [Whitley, (2001), p.35]. As a result, there is a reduced propensity to invest in projects involving intangible assets, i.e., projects with no clear returns, projects unrelated to industrial plans, and projects that do not have a direct impact on efficiency and cost reductions.

Chinese firms seem to be in need for well trained professionals, in the field of management, opened to Western standards and sensitive to the instruments and tools that can help human resource coordination and support the development of a customer-oriented attitude/philosophy.

From the Chinese perspective, the Go Global policy should encourage, through appropriate instruments (training, first of all), the growth of managerial skills of the persons who are in charge to manage the post acquisition phase. To optimise the benefit of M\&A, governments should encourage firms to pay attention to the mechanisms to boost coordination of human resources and development of relational capital. The Go Global policy should also encourage the development of a high sensitivity to the needs and characteristics of the Western markets, where a key role is played by customer service (both internal and external) and by intangible resources (and investments related to them). Western governments that are trying to attract Chinese investments to save industries or national firms in financial distress or market difficulties should attempt to mitigate the risk of failure by providing bridge programmes for cultural integration.

A research design that also allows access to headquarter will allow for a deeper understanding of the organisational culture and motivations, beyond what is publicly revealed. However, Chinese organisations are notoriously sensitive and secretive about revealing information, and access to their inner-workings and strategic thinking is not easy to come by. Future research focusing on ethnographies of Chinese corporations can greatly help move the field forward on the inner working and motivations of Chinese international acquisitions. 


\section{References}

Accenture (2005) 'China spreads its wings - Chinese companies Go Global', available at http://www.accenture.com/us-en/Pages/insight-china-spreads-wings-chinese-companies-goglobal-summary.aspx (accessed on 3 January 2012).

Alon, I. and McIntyre, J. (Eds.) (2008) The Globalization of Chinese Enterprises, Palgrave MacMillan, New York.

Alon, I. and Higgins, J.M. (2005) 'Global leadership success through emotional and cultural intelligences’, Business Horizons, Vol. 48, No. 6, pp.501-512.

Alon, I. et al. (Eds.) (2009) China Rules: Globalization and Political Transformation, Palgrave Macmillan, New York.

Alon, I., Fetscherin, M. and Gugler, P. (Eds.) (2011) Chinese International Investments, Palgrave MacMillan, New York.

Asia-Pacific Foundation of Canada (APFC) and China Council for the Promotion of International Trade (CCPIT) (2009) China Goes Global, Vancouver, BC.

Aykut, D. and Goldstein, A. (2006) 'Developing countries multinationals: south-south investment comes of age’, OECD Working Paper No. 257.

Bartlett, C.A. and Ghoshal, S. (2000) 'Going global: lessons from late movers', Harvard Business Review, Vol. 78, No. 2, pp.132-142.

Battat, J. (2006) China's Outward Foreign Direct Investment, Foreign Investment Advisory Services, World Bank Group, Washington, DC.

Bellabona, P. and Spigarelli, F. (2007) 'Moving from open door to go global: China goes on the world stage', International Journal on Chinese Culture and Management, Vol. 1, No. 1, pp.93-107.

Bert, A., Sleigh, A. and Tse, M. (2009) 'The six things Chinese acquirers must get right when venturing overseas', available at http://www.accenture.com/SiteCollectionDocuments/PDF/Accenture_POV_The_six_thingsCh inese_acquirers_must_get_right_when_venturing_overseas.pdf (accessed on 3 January 2012).

Boateng, A., Wang, Q. and Yang, T. (2008) 'Cross-border M\&As by Chinese firms: an analysis of strategic motives and performance’, Thunderbird International Business Review, Vol. 50, No. 4, pp.259-270.

Bonaglia, F., Goldstein, A. and Mathews, J.A. (2007) 'Accelerated internationalization by emerging markets' multinationals: the case of the white goods sector', Journal of World Business, Vol. 42, No. 4, pp.369-383.

Buckley, P.J. et al. (2007) 'The determinants of Chinese outward foreign direct investment', Journal of International Business Studies, Vol. 38, No. 4, pp.499-518.

Buckley, P.J. et al. (2008) 'Historic and emergent trends in Chinese outward direct investment', Management International Review, Vol. 48, No. 6, pp.715-748.

Chen, Q.T. and Li, D.S. (2006) Annual Report on the Development of China's Large Enterprise Groups: Cross-border M\&A and China's Large Enterprise Groups, Development Press, Beijing.

Child, J. and Rodrigues, S.B. (2005) 'The internationalization of Chinese firms: a case for theoretical extension?', Management and Organization Review, Vol. 1, No. 3, pp.381-410.

Cross, A.R. and Voss, H. (2008) 'Chinese direct investment in the United Kingdom: an assessment of motivations and competitiveness', Paper presented at the Corporate Strategies in the New Asia, 1-2 February, University of Bremen.

Deng, P. (2004) 'Outward investment by Chinese MNCs: motivations and implications', Business Horizons, Vol. 47, No. 3, pp.8-16.

Deng, P. (2007) 'Investing for strategic resources and its rationale: the case of outward FDI from Chinese companies', Business Horizons, Vol. 50, No. 1, pp.71-81. 
Deng, P. (2009) 'Why do Chinese firms tend to acquire strategic assets in international expansion?', Journal of World Business, Vol. 44, No. 1, pp.74-84.

Dyer, J.H. and Chu, W. (2003) 'The role of trustworthiness in reducing transaction costs and improving performance: empirical evidence from the United States, Japan, and Korea', Organization Science, Vol. 14, No. 1, pp.57-68.

Economist Intelligence Unit (EIU) (2010) 'A brave new world. The climate for Chinese M\&A abroad', available at http://www.eiu.com/site_info.asp?info_name=eiu_The_climate_for_ Chinese_MandA_abroad\&rf=0 (accessed on 4 January 2012).

Franke, R.H., Hofstede, G. and Bond, M.H. (1991) 'Cultural roots of economic performance: a research note’, Strategic Management Journal, Summer, Vol. 12, pp.165-173.

Galbraith, J.R. (1977) Organization Design, Addison-Wesley, Reading, MA.

Gammeltoft, P. (2008) 'Emerging multinationals: outward FDI from the BRICS countries', International Journal of Technology and Globalisation, Vol. 4, No. 1, pp.5-22.

Goldstein, A. (2008) 'Who's afraid of emerging-market TNCs? or: are developing countries missing something in the globalization debate?', in Sauvant, K.P. (Ed.): The Rise of Transnational Corporations From Emerging Markets: Threat or Opportunity?, pp.183-203, Edward Elgar, Cheltenham.

Haspeslagh, P.C. and Jemison, D.B. (1991) Managing Acquisitions: Creating Value through Corporate Renewal, Free Press, New York.

Hess, W. (2006) 'Going outside, round-tripping and dollar diplomacy: an introduction to Chinese outward direct investment', World Market Analysis, January, Global Insight Inc., available at http://www.ihsglobalinsight.com/Highlight/HighlightDetail2717.htm?CFID=14301141\&CFT OKEN=93276862 (accessed on 4 January 2012).

Hirt, M. and Orr, G. (2006) 'Helping China's companies master global M\&A', McKinsey Quarterly, No. 4, pp.38-49.

House, R. et al. (2004) Leadership Culture and Organizations: The GLOBE Study of 62 Societies, Sage, Thousand Oaks, CA.

Jiang, W. (2006) 'Survey: firms achieve goals abroad', China Daily, 14 June.

Kale, P. and Singh, H. (2008) 'Emerging multinationals: a partnering approach to acquisitions'. Paper presented at the Strategic Management Society India Conference, Hyderabad, India.

Kale, P. and Singh, H. (2009) 'Managing strategic alliances: what do we know now, and where do we go from here?', Academy of Management Perspectives, Vol. 23, No. 2, pp.45-62.

Lawrence, S.V. (2002) ‘Going global’, Far Eastern Economic Review, Vol. 165, No. 12, p.32.

Liu, H. and Li, K. (2002) 'Strategic implications of emerging Chinese multinationals: the Haier case study’, European Management Journal, Vol. 20, No. 6, pp.699-706.

Liu, L. and Tian, Y. (2008) 'The internationalisation of Chinese enterprises: the analysis of the UK case', International Journal of Technology and Globalisation, Vol. 4, No. 1, pp.87-102.

Mathews, J.A. (2002) Dragon Multinational: A New Model of Global Growth, Oxford University Press, New York.

McEvily, B., Perrone, V. and Zaheer, A. (2003) 'Trust as an organizing principle’, Organization Science, Vol. 14, No. 1, pp.91-103.

Meyer, K. (1998) Direct Investment in Economies in Transition, Edward Elgar, Cheltenham.

Meyer, M.W. (2008) 'China's second economic transition: building national markets', Management and Organization Review, Vol. 4, No. 1, pp.3-15.

Miller, J. (2011) 'Chinese companies embark on shopping spree in Europe', The Wall Street Journal, 7 June.

MOFCOM (2009) '2007 statistical bulletin of China's outward foreign direct investment', available at http://tradeinservices.mofcom.gov.cn/en/c/2009-04-10/70585.shtml (accessed on 4 January 2012). 
Morck, R., Yeung, B. and Zhao, M. (2008) 'Perspectives on China's outward foreign direct investment', Journal of International Business Studies, Vol. 39, No. 3, pp.337-350.

Morgan Stanley (2005) 'China’s M\&A', Chinese Executive Learning Programme, (Judge Business School and Cambridge China Development Trust), Vol. 1, pp.251-281, University of Cambridge, UK.

Nolan, P. (2001) China and the Global Economy: National Champions, Industrial Policy, and the Big Business Revolution, Palgrave, New York.

Nolan, P. and Zhang, J. (2002) 'The challenge of globalization for large Chinese firms', World Development, Vol. 30, No. 12, pp.2089-2107.

OECD (2008) China 2008: China Encouraging Responsible Business Conduct, Paris.

Oliver, C. (1997) 'Sustainable competitive advantage: combining institutional and resource-based views’, Strategic Management Journal, Vol. 18, No. 9, pp.697-713.

People's Daily Online (2009) 'Chinese firms' outbound investment to face simplified procedures', 18 September, available at http://english.peopledaily.com.cn/90001/90778/90857/90861/6761782.html (accessed on 4 January 2012).

Ramamurti, R. (2009) 'What have we learned about emerging-market MNEs?', in Ramamurti, R. and Singh, J.V. (Eds.): Emerging Multinationals in Emerging Markets, pp.399-426, Cambridge University Press, Cambridge, UK.

Rossele-McCauley, S. (2009) 'The nuts and bolts of China’s competitiveness, the story of a country's rise and the challenges ahead available', IMD, available at http://www.imd.ch/research/challenges/TC076-09.cfm (accessed on 4 January 2012).

Rui, H. and Yip, G.S. (2008) 'Foreign acquisitions by Chinese firms: a strategic intent perspective', Journal of World Business, Vol. 43, No. 2, pp.213-226.

Sauvant, K.P. (2005) 'New sources of FDI: the BRICs outward FDI from Brazil, Russia, India and China', Journal of World Investment \& Trade, Vol. 6, No. 5, pp.639-709.

Sauvant, K.P. (2006) 'Inward and outward FDI and the BRICs', in Jain, S.B. (Ed.): Emerging Economies and the Transformation of International Business: Brazil, Russia, India and China, Edward Elgar, Cheltenham, pp.313-409.

Sauvant, K.P. (2008) 'The rise of TNCs from emerging markets: the issues', in Sauvant, K.P. (Ed.): The Rise of Transnational Corporations From Emerging Markets: Threat or Opportunity?, Edward Elgar, Cheltenham, pp.3-14.

Schreiner, M., Kale, P. and Corsten, D. (2009) 'What really is alliance management capability and how does it impact alliance outcomes and success?', Strategic Management Journal, Vol. 30, No. 13, pp.1395-1418.

Spigarelli, F. (2010) 'Chinese investments in Italy: is the wave arriving?', International Journal of Asian Business and Information Management, Vol. 1, No. 1, pp.54-76.

Spigarelli, F., Alon, I. and Wei, W. (2009) 'A speed race: Beneli and QJ competing on the motorbike international arena', Case study 8B09M97, Richard Ivey School of Business Foundation, University of Western Ontario.

Tan, W. (2005) 'Culture conflicts in Sino-Foreign ventures’, Beijing Review, Vol. 48, No. 25, pp.40-41.

Taylor, R. (2002) 'Globalization strategies of Chinese companies: current developments and future prospects', Asian Business and Management, Vol. 1, No. 2, pp.209-225.

UNCTAD (2006) 'World investment report 2006: FDI from developing and transition economies: implications for development', New York and Geneva, available at http://www.unctad.org/en/docs/wir2006_en.pdf (accessed on 4 January 2012).

UNCTAD (2010) 'World investment report 2010: investing in a low-carbon economy', New York and Geneva, available at http://www.unctad.org/en/docs/wir2010_en.pdf (accessed on 4 January 2012). 
UNCTAD (2011) 'World investment report 2011: non-equity modes of international production and development', New York and Geneva, available at http://www.unctaddocs.org/UNCTAD-WIR2011-Full-en.pdf (accessed on 4 January 2012).

Whitley, R. (1999) Divergent Capitalisms: The Social Structuring and Change of Business Systems, Oxford University Press, Oxford.

Whitley, R. (2001) 'How and why are international firms different? The consequences of cross-border managerial coordination for firm characteristics and behaviour', in Morgan, G., Kristensen, P.H. and Whitley, R. (Eds.): The Multinational Firm: Organizing across Institutional and National Divides, pp.27-68, Oxford University Press, Oxford.

Whitley, R. (2005) 'How national are business systems? The role of states and complementary institutions in standardizing systems of economic coordination and control at the national level', in Morgan, G., Whitley, R. and Moen, E. (Eds.): Changing Capitalisms? Internationalism, Institutional Change, and Systems of Economic Organization, pp.190-231, Oxford University Press, Oxford.

Wilson, D. and Purushothaman, R. (2003) 'Dreaming with BRICs: the path to 2050', Global Economics Paper, No. 99, available at http://www2.goldmansachs.com/our-thinking/ brics/brics-reports-pdfs/brics-dream.pdf (accessed on 4 January 2012).

Yeung, H.W. and Liu, W. (2008) 'Globalizing China: the rise of mainland firms in the global economy’, Eurasian Geography and Economics, Vol. 49, No. 1, pp.57-86.

Yin, R.K. (1989) Case Study Research: Design and Methods, Sage Publications, London.

Zhang, K. (2005) Going Global: The Why, When, Where and How of Chinese Companies' Outward Investment Intention, Canada in Asia Series 2005-5, Asia Pacific Foundation of Canada, Vancouver.

Zhang, Y. (2003) China's Emerging Global Businesses: Political Economy and Institutional Investigations, Palgrave Macmillan, Basingstoke.

Zollo, M. and Singh, H. (2004) 'Deliberate learning in corporate acquisitions: post-acquisition strategies and integration capabilities in U.S. bank mergers', Strategic Management Journal, Vol. 25, No. 13, pp.1233-1256.

Zweig, D. (2002) Internationalizing China: Domestic Interests and Global Linkages, Cornell University Press, Ithaca.

\section{Notes}

1 For an up-to-date literature review on the motivations behind cross-border M\&As see Boateng et al. (2008).

2 The post-acquisition phase is generally characterised by three stages: 'enthusiasm' (the buyer believes that its business and management approaches will be successful in Western markets); 'growing discomfort' (communication becomes frustrating, with increasing difficulties due to cultural and geographical barriers); and the 'need to change' (the buyer replaces some managers, including expatriates, and launches programs to bridge cultural gaps and solve communication problems). See Hirt and Orr (2006).

3 This case study was developed using various sources: corporate materials, balance sheets and the Internet. The most valuable in-depth information was derived from repeated direct, openended and non-structured interviews with executives, top- and middle-level managers and shop-floor workers. There were also some informal follow-ups with e-mails and phone calls. Field visits and interviews were carried out from 2008 to 2010. The interviews were not taped and anonymity was preserved. The exchange of information (as well as of rumours, anecdotes and feelings) was particularly intense with three key persons in the company, all of whom were Italians: the vice managing director, the CFO and the press officer. Contacts with Chinese employees were limited. No direct interviews were held with anyone from the Chinese parent company. This, of course, is a limitation of the case analysis. 
4 Changes may be related to increased autonomy from domestic pressure groups, the severing of links with domestic business partners, a mix of new objectives as the company has to deal with different stakeholders and interests, and a loss of organisational cohesion and integration [Whitley, (1999), p.123].

5 China is one of the top sources of state-owned transnational corporations: 50 out of 653 state-owned companies operating worldwide are Chinese [UNCTAD, (2011), p.31].

6 Registrations in Italy were 444,987 in 2007 and 307,045 in 2010. In 2009, motorbikes experienced a $-20.2 \%$ decrease, falling back to the 1999 volume. Such a large reduction continued in the first months of 2011: from January to March 2011 registrations decreased by 21.33\% compared to the same period of 2010 (http://www.ancma.it).

7 No particular changes were made in the evaluation criteria that the Italian firm used to draw up its financial statement or in the structure of the basic information provided to the parent company. 